Aletria, Belo Horizonte, v. 31, n. 1, p. 55-78, 2021

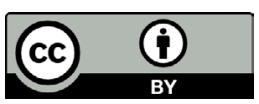

\title{
Como fazer um Livro do Desassossego
}

\section{How to Make a Book of Disquiet}

\author{
Marcelo Cordeiro de Mello \\ Universidade Federal de Minas Gerais (UFMG), Belo Horizonte, Minas Gerais / Brasil \\ marcelocmello@gmail.com \\ http://orcid.org/0000-0001-6880-7503
}

Resumo: O Livro do Desassossego, obra que Fernando Pessoa não terminou nem organizou, deixa a quaisquer editores uma série de dilemas que decorrem de sua própria natureza fragmentária e irregular: é uma obra assinada por diferentes heterônimos, composta em diferentes momentos e enfim deixada de lado pelo autor. O presente artigo procura comparar e analisar diferentes edições do Livro do Desassossego, desde as mais antigas e tradicionais até as mais modernas e experimentais. Para tanto, procura entender o Livro do Desassossego dentro do contexto da produção pessoana, e faz referência a obras de autores da Teoria Literária, como Gérard Genette e Roland Barthes, que refletiram sobre a natureza do objeto livro. A ideia é propor uma reflexão sobre a tarefa do editor e as possibilidades que a ele se apresentam diante de uma obra de tão problemática organização.

Palavras-chave: Fernando Pessoa; Bernardo Soares; Livro do Desassossego; livro; edição; organização.

Abstract: The Book of Disquiet, a literary work that Fernando Pessoa has not finished nor organized, presents to any editor a series of dilemmas that arise of its very nature, fragmentary and irregular: it is a work signed by different heteronyms, composed in different moments and eventually put aside by its author. This article aims to compare and analyze different editions of the Book of Disquiet, from the earliest and more traditional ones to the more modern and experimental ones. For this purpose, it tries to place the Book of Disquiet within the context of Pessoa's production, and it references the works of authors of Literary Theory, like Gérard Genette and Roland Barthes, 
both of who have written on the nature of the book object. The idea is to propose a reflection about the editor's task and the possibilities that appear before a work of such problematic organization.

Keywords: Fernando Pessoa; Bernardo Soares; Book of Disquiet; book; edition; organization.

Por que escrevo eu este livro? Porque o reconheço imperfeito. Calado seria a perfeição; escrito, imperfeiçoa-se; por isso o escrevo.

Bernardo Soares, Livro do Desassossego

Livros são papéis pintados com tinta Fernando Pessoa, "Liberdade"

Dos vinte e sete mil quinhentos e quarenta e três papéis do espólio de Fernando Pessoa (PESSOA, 1982, p. 25) - hoje pertencentes à Biblioteca Nacional Portuguesa - existem entre 450 e 500 trechos que formam o que costumamos chamar de "Livro do Desassossego" (PESSOA, 1997, p. 31). Destes, apenas doze trechos foram publicados em vida. Mas o Livro do Desassossego existe? É possível defini-lo? Com que precisão? O Livro do Desassossego é, de fato, um livro?

\section{Preâmbulo}

O projeto de um Livro do Desassossego é concebido e desenvolvido na imaginação pessoana em dois períodos: de 1913 a 1915; e, depois, de 1927 a 1934.

A primeira fase precede e coincide com a atividade do grupo da revista Orpheu. Pessoa escreve um primeiro fragmento intitulado $\mathrm{Na}$ floresta do alheamento, que é publicado em 1913 na revista A Águia. A autoria é atribuída ao próprio Fernando Pessoa, trazendo a indicação: "Do Livro do Desassossego, em preparação". É surpreendente notar que, supostamente, a ideia nasce mais de um ano antes do trio heteronímico que o consagraria: Alberto Caeiro, Álvaro de Campos e Ricardo Reis. Nesta época, Pessoa não tinha o hábito tão rígido de datar seus escritos. Mesmo assim, uma complicada análise de caligrafias, papéis, tintas (cores 
e intensidades) permitiu aos estudiosos pessoanos ${ }^{1}$ fazer uma datação mais ou menos segura de determinados textos, em especial os da primeira fase do Livro do Desassossego. Os textos desta fase se aproximam do estilo simbolista-decadentista de Na Floresta do Alheamento: numa fluida prosa carregada de traços poéticos (ritmo, aliterações e assonâncias), vaise construindo uma paisagem textual onírica, frequentemente colorida por medievalismos e orientalismos. São sonhos que materializam, na própria escrita, contornos, sonoridade e visualidade. Paralelamente, há momentos em que o tom de diário sobressai, e a realidade cotidiana de Lisboa oferece matéria para alimentar o sonho.

Em 1915 (ou talvez já em 1914), Pessoa passa a atribuir a autoria dos escritos do Livro do Desassossego ao heterônimo Vicente Guedes, funcionário da Baixa lisboeta. Porém esta produção não dura muito tempo. O Livro do Desassossego entra num estado de dormência a partir do período que coincide com a morte de Mário de Sá-Carneiro.

Em 1927 ou 1928, por alguma razão, Pessoa volta a produzir uma prosa que ele próprio identificará com os textos do Livro do Desassossego escritos mais de uma década antes. Em 1929, o autor passa a definir o semi-heterônimo Bernardo Soares como autor do Livro do Desassossego. Nesta altura, Pessoa já mantém com muito mais rigor o hábito de datar seus escritos. É dessa época o frontispício (publicado na edição organizada por Richard Zenith) que traz a seguinte menção: "Livro do Desassossego. Composto por Bernardo Soares, ajudante de guarda-livros na cidade de Lisboa". Retomando o topos literário do "manuscrito encontrado", um prefácio assinado por Fernando Pessoa explica como ele teria conhecido Soares num restaurante e se tornado o guardião dos seus escritos. Num elaborado jogo de despersonalização como uma espécie de Pierre Menard que sentasse à mesa com Quixote e Borges - Pessoa problematiza a questão da autoria ao incluir o seu próprio nome de ortônimo no papel de (pseudo-)editor. A premissa de sua escrita heteronímica é respeitada, mas apenas parcialmente.

Pessoa manifestou a intenção de retomar os fragmentos da primeira fase do Livro do Desassossego para adaptá-los, conformando-os à "vera psicologia" (PESSOA, 1982, p. 8) do semi-heterônimo Soares.

\footnotetext{
${ }^{1}$ Referimo-nos especialmente às pesquisadoras Maria Aliete Galhoz e Teresa Sobral Cunha, que estabeleceram a primeira versão do texto do Livro do Desassossego, bem como ao pesquisador Richard Zenith, que mais recentemente dedicou-se à mesma tarefa.
} 
Ainda assim, é possível identificar uma clara continuidade entre a biografia de Guedes e a de Soares. Ambos transitam por Lisboa, onde moram e trabalham em escritórios comerciais (não por acaso, como também o seu próprio criador, Pessoa). Presume-se que Guedes tenha uma condição econômica mais favorável do que Soares - para quem é constante o tema de uma pretensa aristocracia de espírito, em oposição à vida modesta que levava. ${ }^{2}$

Com o desaparecimento de Guedes, passando a ser Soares o único autor do livro, são mantidos o tom e o formato fragmentário dos trechos da primeira fase, e é extrapolada ainda mais a hesitação, criando um tipo de texto ainda mais lacunar e indeciso. Reconhece-se também nesta segunda fase a preferência do semi-heterônimo Bernardo Soares pelo uso de títulos grandiosos (dos quais falaremos adiante).

$\mathrm{Na}$ fase soariana, é possível identificar pelo menos dois tipos de textos: se por um lado continuam existindo textos oníricos como os da fase guediana, começam a surgir também trechos que explicam o procedimento de sonho empregado na escrita dos trechos oníricos. É claro que inúmeros trechos poderiam ser incluídos numa categoria intermediária: sonham ao mesmo tempo em que explicam o método de sonhar. Há ainda (embora em menor escala em comparação com Guedes) um certo tom diarístico. Nesta "autobiografia sem factos", Soares não narra eventos significativos de sua existência, mas sim momentos banais de sua rotina. $\mathrm{O}$ estilo de Pessoa-Soares parece nascer como tentativa de superar, dentro do espaço da escrita, a alienação cotidiana, na fruição da linguagem como gozo.

Dentro da concepção que Pessoa tinha de sua obra, o termo semi-heterônimo é aplicado unicamente a Soares. Ele designa uma personalidade que não seria diferente da de Pessoa, mas uma simples "mutilação" desta. O próprio nome do semi-heterônimo soa claramente como uma corruptela do nome de seu criador: não por acaso, Bernardo soa como Fernando; Soares soa como Pessoa:

\begin{tabular}{|l|c|}
\hline fERNAnDO & pESSOA \\
bERNArDO & SOArES \\
\hline
\end{tabular}

\footnotetext{
${ }^{2}$ Surgirão ainda trechos do Livro do Desassossego escritos por um terceiro heterônimo (sobre o qual não nos aprofundaremos aqui), este sim um "autêntico" aristocrata: o Barão de Teive.
} 


\section{A obra Livro do Desassossego}

Alguns anos antes de sua morte, Pessoa recolheu num grande envelope papéis com escritos que pretendia um dia incluir no Livro do Desassossego - escritos que, é claro, deveriam antes passar por uma revisão e reformulação, em que provavelmente uma parte deles seria eliminada. Este envelope deu origem ao corpus que foi a base para as diferentes edições do Livro do Desassossego.

Os livros que se apresentaram como edições do Livro do Desassossego são pelo menos cinco principais. Nossa ênfase está em duas edições: a edição princeps, publicada pela Editora Ática em 1982, organizada por Maria Aliete Galhoz e Teresa Sobral Cunha; e especialmente a edição organizada por Richard Zenith, publicada pela Assírio \& Alvim e republicada no Brasil pela Companhia das Letras. ${ }^{3}$ Ocasionalmente, faremos referência também a outras edições.

Fernando Cabral Martins, editor e organizador do Dicionário de Fernando Pessoa e do Modernismo Português, considera a edição de Richard Zenith "certamente a mais fiel" (MARTINS, 2008, p. 814). Mas talvez seja também a mais conservadora - nela só entraram os textos para os quais há indícios reais de pertencimento ao Livro do Desassossego: ou por terem sido incluídos no grande envelope, ou por trazerem a indicação abreviada "L. do D.". Não sabemos nem saberemos a ordem em que os papéis se encontravam dentro do tal envelope. Tampouco sabemos ao certo se essa ordem teria importância para a obra dentro da concepção de seu autor. O que sabemos é que o conteúdo do envelope foi desdobrado em cinco outros envelopes e que, a partir dessa ordem (ou desordem) inicial, foram estabelecidos as cotas e os números de tombo de cada papel referente ao Livro do Desassossego. Todo este material foi microfilmado e atualmente encontra-se disponível para consulta na Casa Fernando Pessoa em Lisboa (enquanto os originais, como vimos, estão em poder da Biblioteca Nacional).

Embora não tenha sido terminado, o Livro do Desassossego foi começado duas vezes. Há uma dualidade na sua própria elaboração, referente às fases de Vicente Guedes e Bernardo Soares - triangulada ainda com um terceiro heterônimo, o Barão de Teive. É importante notar que o projeto do livro não acompanha Pessoa até a sua morte. $\mathrm{O}$

\footnotetext{
${ }^{3}$ Utilizaremos aqui a edição brasileira da Companhia das Letras.
} 
último trecho datado do Livro do Desassossego encontrado no espólio data de mais de um ano antes da morte do autor, dando a entender que o livro teria voltado a entrar em hibernação no final da vida do autor. Aqueles que tinham se apressado em atribuir a não conclusão do Livro do Desassossego à morte prematura do autor, sabendo desta fase de hibernação, certamente ficarão com a pulga atrás da orelha.

\section{Como fazer um Livro do Desassossego?}

Como vimos, há um aspecto curioso na autoria do Livro do Desassossego. Embora Bernardo Soares seja seu autor, ${ }^{4}$ o nome de Fernando Pessoa se apresenta (sutilmente) como uma espécie de organizador ou editor da obra. Parece simbólico o fato de o próprio Pessoa ter se colocado como (pseudo-)editor deste livro em que as opções de edição são tão determinantes - a ponto de terem conseguido gerar, a partir de um corpus comum, livros completamente diferentes. Qualquer um que se disponha à tarefa de editar o Livro do Desassossego terá que atravessar pelo menos três complexas etapas. Embora a organização de qualquer livro enfrente (em maior ou menor medida) estes três desafios, é interessante observar como o exemplo do Livro do Desassossego radicaliza estas e outras problemáticas metaliterárias.

A primeira etapa (talvez a mais difícil delas) é o estabelecimento do texto. Um problema que não deve ser subestimado é a dificuldade de decifrar os garranchos pessoanos. Se a caligrafia do autor nunca foi facilmente legível, muito menos o seria nos trechos da última fase do Livro do Desassossego, em que escrevia sob forte influência do álcool, substância cujo abuso causaria sua morte em 1935, em decorrência de uma cirrose hepática. $\mathrm{O}$ alcoolismo certamente influenciou sua caligrafia, deixando-a ainda mais sinuosa e enigmática.

Porém, ainda levando em consideração apenas o problema do estabelecimento do texto, existe outra questão infinitamente mais problemática: é o fato de que o texto contém as hesitações de Pessoa. Como alguém que escreve e reescreve um rascunho aproveitando os vários espaços vazios do papel (dos mais diversos tipos de papel, digase de passagem), Pessoa explorou um uso da espacialidade da página

\footnotetext{
${ }^{4}$ Ou pelo menos, seu autor principal (pelo menos dentro da concepção que aplicamos aqui).
} 
que ia muito além das linhas pautadas. Por entre os parágrafos ou entre as linhas, nas laterais e nas margens - cobrindo quase todo o branco da folha, vão jorrando as variantes (e também as variantes de variantes) que registram a sua hesitação - que muitas vezes é resumida num conciso e enigmático ponto de interrogação, marcando sua dúvida a respeito de uma palavra, uma imagem, uma frase, uma ideia, uma construção - e, talvez, também a dúvida diante da própria obra. Dentre estas diversas variantes de palavras, é óbvio que fica impossível saber qual teria sido aquela finalmente escolhida pelo autor. Para tentar representar esta escrita em palimpsesto, as duas edições em que nos concentramos aqui utilizaram sistemas de sinais gráficos próprios:

\begin{tabular}{|l|l|}
\hline \multicolumn{1}{|c|}{ Ática } & Assírio \& Alvim / Companhia das Letras \\
\hline / / Reserva do Autor acerca de uma palavra & $\square-$ espaço deixado em branco pelo autor \\
ou expressão & {$[\ldots]$ - palavra ou frase não lida } \\
( ) Hesitação do Autor quanto à oportunidade & {$[$ ] - palavra acrescentada pelos editores } \\
da inserção de uma ou mais palavras & {$[?]-$ leitura conjectural } \\
(...) Passagem deixada incompleta pelo Autor & \\
[ ] Palavras acrescentadas pelos editores & \\
[...] Palavra ou passagem ilegível & \\
[?] Incerteza quanto à leitura estabelecida & \\
\hline
\end{tabular}

Embora estas duas edições tenham procurado estabelecer o texto de maneira independente, também acontece com frequência que o editor não "suje as mãos" consultando os manuscritos e, em vez disso, se dedique apenas às duas tarefas seguintes.

A segunda etapa do processo de edição do Livro do Desassossego diz respeito à definição do corpus: escolher o que fica dentro e o que fica fora. É claro que a maioria dos editores partiu do tal envelope contendo os trechos "selecionados" por Pessoa. Naturalmente, somaram-se a eles os inúmeros trechos encontrados na famosa arca em que consta a abreviatura "L. do D.", que permite identificá-los como pertencentes ao Livro do Desassossego. Porém, há exceções dos mais diferentes tipos: existem trechos cujo estilo se harmoniza com o do Livro do Desassossego, mas onde não aparece a abreviatura "L. do D."; há também inúmeros casos de hesitação do próprio autor em relação à classificação de um 
texto: "What's this? Don't know yet"5 anota o autor para si próprio (com o distanciamento que a língua inglesa pressupunha para ele). Um dos trechos incluídos no referido envelope traz a inscrição " $L$. do D. ou A. de C. (?)" indicando que Pessoa teria hesitado entre atribuílo ao Livro do Desassossego ou associá-lo ao heterônimo Álvaro de Campos - personagem que partilha com Soares alguns traços de estilo e personalidade. E, ainda que a autoria esteja explicitada na folha, o que garante que Pessoa não mudaria a atribuição, como fazia frequentemente? E quanto aos trechos assinados por Guedes, devemos considerar que Pessoa simplesmente "não teve tempo" de fazer as adaptações que lhe permitissem fusioná-los com o estilo de Soares? Ou será que o que impossibilitou a fusão, em vez da falta de tempo, não foi a falta de outra coisa - talvez a falta de nexo entre os dois personagens? O problema se complica ainda mais se tentamos incluir o terceiro heterônimo Barão de Teive na discussão. É importante recordar o significativo fato de Pessoa ter "abandonado" o Livro do Desassossego um ano antes de sua morte - o que corroboraria esta hipótese de que o próprio autor teria cedido à dificuldade de organizar o Livro do Desassossego. Em português, o verbo "engavetar" é sinônimo de "interromper" ou "abandonar".

A maioria dos editores das diversas versões do Livro do Desassossego tem atribuído a autoria a Bernardo Soares, com a exceção emblemática da edição princeps da Ática, que foi publicada em dois volumes, o primeiro dedicado a Guedes e o segundo a Soares - duas fases e duas personagens pessoanas - o que reforça um (subterrâneo) critério cronológico na organização. Observe-se, de passagem, que o critério cronológico foi a preocupação, por exemplo, de António Quadros, que reorganizou o corpus da Ática reforçando a ordem em que os trechos foram escritos:

Nesta nova organização que ora apresentamos ao público, fica convenientemente respeitada, não a unidade do Livro, porque não a tem (na ausência da revisão geral do autor), mas a sua realidade plural, consistindo esta realidade em não haver um, mas dois Livros do desassossego: o de Fernando Pessoa-ele próprio, simbolista, decadentista, transcendentalista, neorromântico: e o de Fernando Pessoa Bernardo Soares, ainda nalguns aspectos simbolista, também em muitos aspectos decadentista, mas

5 "O que é isto? Não sei ainda" 
fundamentalmente divagante, sonhador, coloquial, diarístico, confessionalista, homem comum, pequeno empregado comercial a sonhar com o infinito do seu quarto andar da Rua dos Douradores. (PESSOA, 1986, p. 380)

Há também exemplos mais recentes, como a edição organizada por Teresa Rita Lopes, que separa os trechos assinados por Soares, Guedes e pelo terceiro heterônimo, o Barão de Teive, abrindo margem para que se considere a existência de um terceiro Livro do Desassossego (PESSOA, 2015, p. 21).

Voltando à discussão sobre as etapas do processo de edição: a última etapa - depois de escolhidos os trechos e estabelecidos os textos - diz respeito ao ordenamento (ou arrumação) destes trechos. O editor Zenith recusou o critério estritamente cronológico por duas razões: primeiro pela dificuldade de definir a data de certos papéis e, em segundo lugar, por desconfiar da importância de uma organização cronológica. $\mathrm{O}$ próprio Pessoa, na meia dúzia de arrumações (completamente diferentes) que propôs para o Livro do Desassossego, em nenhuma delas levou em conta o critério cronológico. Apesar de rejeitar o critério cronológico, o editor Zenith empreendeu um minucioso trabalho de análise dos papéis manuscritos e datiloscritos, procurando encontrar neles características que permitissem reconstituir suas datas. Tendo feito este trabalho da maneira mais ampla possível, Zenith passou a uma organização que, embora levasse em consideração o aspecto cronológico, não se limitava a ele. Com frequência, aparecem misturados os trechos da fase de Guedes com os da fase de Soares. Outro aspecto que distingue a edição de Zenith é a apresentação no final do livro dos chamados "grandes trechos", que são os trechos com títulos grandiosos.

Deixemos à margem as edições organizadas por António Quadros e Teresa Rita Lopes - que se apoiam em critérios cronológicos e de autoria heteronímica - e concentremo-nos nas duas outras edições que mencionamos: a edição princeps da Ática, organizada por Maria Aliete Galhoz e Teresa Sobral Cunha (1982) e a edição da Companhia das Letras, organizada por Richard Zenith (1997). Nestes casos, os editores usaram critérios temáticos - embora em nenhum dos dois casos tenham deixado claros quais foram estes critérios. A edição princeps da Ática fala em "manchas temáticas, sugerindo nexos e contrastes pela simples justaposição" (PESSOA, 1982): já aqui aparece a noção clara 
de que o simples cotejamento dos trechos criaria diálogos internos, correspondências e choques.

Cabe mencionar, de passagem, a edição crítica do Livro do Desassossego organizada por Jerónimo Pizarro e publicada em 2010 (pela editora Tinta da China): ela procura se livrar, ainda que parcialmente, das obrigações de estabelecimento do texto e de seleção apresentando todas as variantes textuais e escolhendo publicar todo o material passível de pertencer ao Livro do Desassossego. Discutiremos adiante até que ponto seria possível ao editor escapar da última obrigação: o ordenamento dos trechos selecionados.

O trabalho de edição define, em maior ou menor medida, o resultado final constituído pelo livro. Na obra pessoana - e ainda mais no inacabado Livro do Desassossego - está claro que é o editor quem deve terminar o trabalho do escritor, escolhendo entre as variantes textuais, selecionando o corpus e definindo uma ordem de apresentação. Só assim o Livro do Desassossego pode existir: sendo desentranhado do limbo (onde existe, mas apenas como virtualidade) para ser organizado e transformado em livro "real". Qualquer que seja esta organização, é preciso admitir que ela não poderá coincidir com aquela(s) desejada(s) pelo próprio autor. Já mencionamos os seis planos de organização do Livro do Desassossego deixados por Pessoa, completamente diferentes e contraditórios. Se hoje o editor hesita, é porque Pessoa também hesitou, e deixou clara a sua hesitação, que pode ser observada também na abundância de variantes textuais. Esta indecisão parece estar associada à própria personalidade fragmentada do escritor, desdobrada em heterônimos que frequentemente se contradizem. Chegamos aqui a um problema essencial do Livro do Desassossego, o que o estudioso pessoano Haquira Osakabe (2005, p. 419) chamou da "tarefa insolúvel de propor uma organização minimamente consensual da referida obra". Nesta linha, Richard Zenith, editor de Fernando Pessoa, lança uma provocação cujo caráter paradoxal não deixaria de interessar ao próprio Pessoa:

tivesse Pessoa preparado o Livro do Desassossego para publicação e este seria decerto um livro menor [...] Eliminado o que tem de fragmentário e lacunar, o livro ia ganhar força, sem dúvida, mas correria o risco de se tornar "mais um" livro, em vez da obra única que é (ZENITH, 1997, p. 31). 
É surpreendente notar como a aparente fraqueza de um livro pode se tornar justamente a sua força. Seja pelo fato de estar inacabado, seja porque o próprio livro trata da fragmentação, o Livro do Desassossego nos coloca no fogo cruzado do processo criativo pessoano. Nas palavras de outro editor, Jacinto Prado Coelho: "Penetramos aqui, com um trémulo respeito, no laboratório secreto do escritor" (COELHO, 1982, p. 11). O editor - que é o "primeiro" leitor - procura dar uma ordem ao caos que encontra e prepará-lo para uma leitura. Para tanto, é inevitável que tome as rédeas deste projeto pessoano.

\section{4. "Publicar-se-socialização de si próprio. Que ignóbil necessidade!" (PESSOA, 1982, p. 86)}

Mas, de fato, é preciso editar e publicar o Livro do Desassossego? Lembre-se que o próprio Pessoa publicou em vida apenas doze trechos do livro. Embora manifeste nos seus escritos a importância que conferia ao Livro do Desassossego e a vontade de prepará-lo para publicação, não há nada que nos permita afirmar que Pessoa quisesse de fato o que afirmava querer. Parece uma complexa armadilha deixada por Pessoa a si mesmo, esta de engendrar uma obra que parece impossível de ser concluída e publicada.

Os amantes das coincidências numéricas não deixarão de observar que o Livro do Desassossego foi publicado em 1982, portanto 47 anos após a morte do autor (aos 47 anos de idade). A essa altura, já era conhecido o trio heteronímico, mas os leitores de Pessoa não imaginavam encontrar uma obra nova que alterasse completamente a ideia que se tinha do autor. É paradoxal o fato de ter sido o Livro do Desassossego o primeiro a revelar o autor no estrangeiro, em especial nos países de língua inglesa e na Alemanha, país onde o livro se tornou um best-seller que já chega à décima-sexta edição, tendo passado por diversos tradutores e editoras.

O fato é que, na época em que foi escrito, o Livro do Desassossego não era publicável. Imagine-se o escândalo que teriam provocado, no Portugal salazarista, trechos como o Conselho às mal-casadas (por mais inofensivos que eles possam nos parecer hoje em dia). Curioso é comparar o Livro do Desassossego ao único livro ortônimo publicado por Pessoa em vida, Mensagem. Financiada com dinheiro do governo, a publicação do livro amenizou as dificuldades econômicas enfrentadas 
pelo escritor naquela época. Pessoa sabia muito bem que aquela publicação, acompanhada do prêmio literário de cunho nacionalista, era uma manobra feito pelo amigo do tempo de Orpheu, António Ferro, para instrumentalizar a obra do grande poeta e convertê-lo em propagandista do regime de Salazar. A repulsa que lhe inspirava Salazar foi resumida neste epigrama (também impublicável na época): "Este senhor Salazar / É feito de sal e azar. / Se um dia chove, / A água dissolve / O sal, / E sob o céu / Fica só azar, é natural” (PESSOA, 1979, p. 349).

\section{Títulos}

Nas (já referidas) listas de títulos de trechos, encontram-se títulos sugestivos como "Chuva de Oiro" e "As três graças" para os quais (ainda) não foram encontrados os textos correspondentes. Eles podem ter desaparecido, ou talvez nunca tenham existido. Zenith considera que "os títulos, como os heterônimos, eram esboços para completar, promessas para cumprir, servindo deste modo para estimular a criatividade de Pessoa" e observa que "o espólio de Pessoa está repleto de títulos para poemas, contos, opúsculos e livros inteiros que nunca existiram" (ZENITH, 1997, p. 17). Pessoa assumiu para si uma noção bem típica das vanguardas do século XX: a de que o título faz parte da obra. Embora tenha alterado três vezes a autoria da obra (do Pessoa ortônimo para Guedes e enfim para Soares, isto sem falar nos trechos assinados pelo Barão de Teive), o autor manteve-se sempre fiel ao título. Estaria a unidade da obra justamente aí, no título?

O Livro do Desassossego é uma obra que procura, desde o título, afirmar-se como livro. Chama a atenção o fato de que a palavra "livro" aparece duas vezes, no título e no subtítulo: "Livro do Desassossego. Composto por Bernardo Soares, ajudante de guarda-livros na cidade de Lisboa". Fica nítido o desejo de opor dois sentidos da palavra-primeiro, o "Livro" com inicial maiúscula, tido como a obra literária. Depois, dentro de uma palavra composta, que nos indica que Bernardo Soares é o guardião não apenas daquela obra literária, mas também de livros não-literários, que resumem em si, por meio de indicações e números, a materialidade do mundo real e da "cidade letrada" (RAMA, 1985); o uso do plural e a falta da inicial maiúscula acentuam a desimportância destes outros "livros", acentuando o contraste em relação ao "Livro" uno, singular. Por outro lado, o caráter abstrato da palavra "desassossego" 
contrasta com a materialidade do objeto-livro, formando um títulocharada. $\mathrm{O}$ crítico e teórico literário Gérard Genette lembra que o título atinge muito mais pessoas do que propriamente os leitores do livro: os destinatários do título são muitos mais do que apenas o destinatário do texto. Confrontado a um título-enigma, cabe ao leitor ceder ou não à provocação. Vale aqui lembrar das palavras de Umberto Eco, citadas por Genette (2009, p. 89): "um título [...] deve embaralhar as ideias e não organizá-las em brigada". Assim, a função do título não é só a identificação; em casos como o do Livro do Desassossego, o título parecer servir mais para confundir e intrigar do que para informar.

\section{Limites}

O processo de edição de um Livro de Desassossego trabalha necessariamente com o problema dos limites.

A primeira etapa, do estabelecimento do texto, coloca o problema dos limites entre texto e paratexto. A indicação de variantes prolifera no texto do Livro de Desassossego, sem que fiquem claras as fronteiras de um texto-base, em torno do qual as variantes orbitariam.

$\mathrm{Na}$ etapa de seleção dos trechos, o problema dos limites se radicaliza. Sabemos que, em geral, o problema básico da maioria dos editores foi procurar a unidade nos trechos incluídos por Pessoa no grande envelope. Esta seleção daria os limites do entendimento que o autor tinha da obra. Ainda que muitos trechos com a indicação "L. do D." tenham ficado de fora do envelope, a ideia de totalidade que existe nos trechos incluídos dentro do envelope permite a um eventual editor transpor seu "espírito" para fora do corpus estritamente "envelopado" pela aprovação pessoana. Some-se a isso o problema (já referido) de que o próprio autor desconhecesse os limites entre seus escritos e incluísse com frequência a indicação de dúvida: "Ainda não sei". ${ }^{6}$

Há também os limites da (sub-)autoria heteronímica, problema básico da obra pessoana. No Livro do Desassossego, há, primeiro, o problema dos limites entre o heterônimo Vicente Guedes e o semiheterônimo Bernardo Soares (e também do Barão de Teive, dependendo dos critérios do editor). Depois, entre o ortônimo Fernando Pessoa,

\footnotetext{
${ }^{6}$ Observe-se, de passagem, que a negação "Não sei” é uma constante de Pessoa, aparecendo algumas centenas de vezes em sua obra.
} 
(pseudo-)editor do Livro do Desassossego, e o semi-heterônimo Soares os dois personagens em que se concentra a autoria do Livro: poderíamos batizar de "PesSoares" esta heterotopia (FOUCAULT, 2013), explorando a (já apontada) semelhança entre os sobrenomes.

Lidar com o Livro do Desassossego é enfrentar a complexidade de, por um lado, encontrar trechos bem acabados, que parecem ter sido escritos e reescritos com tempo e atenção e, por outro lado, deparar-se com trechos fragmentários, fruto de uma inspiração ocasional e efêmera, mero esboço ou indicação (supostamente) destinada a um desenvolvimento futuro. Mais adiante trataremos do problema dos fragmentos.

A prosa "musicante" (PESSOA, 1966, p. 103) do Livro do Desassossego nos põe diante do problema do limite entre prosa e poesia. Zenith observa que, na prosa pessoana, a decifração dos manuscritos é ainda mais complicada, não havendo o apoio da métrica e da rima (ZENITH, 1997, p. 7).

O Livro do Desassossego é também o livro da fronteira entre o ficcional e o biográfico; além, é claro, de ser o livro do limite entre o sonho e a realidade. Sua concepção estética apoia-se precisamente neste caráter fronteiriço, que o define.

\section{Antilivro?}

O Livro do Desassossego- sempre provisório, indefinido e em transição - é uma daquelas raras obras onde la forme et le fond se refletem perfeitamente. Sempre com a intenção de rever e organizar os fragmentos, mas sem coragem ou paciência para enfrentar a tarefa, Pessoa foi acrescentando material, e os parâmetros da obra amorfa dilatavam-se (ZENITH, 1997, p. 19).

No parágrafo citado acima, encontramos uma curiosa contradição do editor Richard Zenith (na introdução de sua edição do Livro do Desassossego) que está bem de acordo com o caráter paradoxal do Livro do Desassossego: como pode haver equilíbrio entre fundo e forma numa obra sem forma (amorfa)? O Livro do Desassossego é frequentemente aproximado de noções como a de "não-livro" ou "antilivro" (ZENITH, 1997, p. 13). Em certa medida, o Livro do Desassossego pode, de fato, ser associado à noção barthesiana de antilivro, descrito como um livro que pretende "dizer não ao livro por meio do livro" (BARTHES, 2005, p. 115). 
Este paradoxo está expresso na vontade do Livro do Desassossego de se afirmar como livro, apesar da dificuldade de ser identificado como tal.

O Livro do Desassossego, por constituir um mero sonho verbalizado, um devaneio linguageiro, aproxima-se do pensamento desconstrutivista. Zenith considera que:

A falta de um centro, a relativização de tudo (inclusive da própria noção de "relativo"), o mundo todo reduzido a fragmentos que não fazem um verdadeiro todo, apenas texto sobre texto sobre texto sem nenhum significado e quase sem nexo - todo este sonho ou pesadelo pós-modernista não foi, para Pessoa, um grandioso discurso. Foi a sua íntima experiência e tênue realidade. (ZENITH, 1997, p. 13)

\section{8. "Fragmentos, fragmentos, fragmentos"}

Uma das dificuldades de se estabelecer uma uniformidade para o Livro do Desassossego é o fato de ele ser formado de pequenos pedaços. Comumente chamados de "trechos", estes textos trabalham com a noção de fragmento - recorrente na passagem do século XIX para o XX. Muitos trechos não foram concluídos, o que acentua seu caráter fragmentário. Segundo Roland Barthes, o fragmento

implica um gozo imediato: é um fantasma de discurso, uma abertura de desejo. Sob a forma de pensamento-frase, o germe do fragmento nos vem em qualquer lugar: no café, no trem, falando com um amigo (surge naturalmente daquilo que ele diz ou daquilo que digo); a gente tira então o caderninho de apontamentos, não para anotar um "pensamento", mas algo como o cunho, o que se chamaria outrora um "verso" (BARTHES, 1977, p. 102).

Assim sendo, não é difícil adivinhar as razões da opção de Pessoa pelo fragmento, sendo ele o autor de uma obra fragmentária cuja manifestação máxima é a fragmentação dos eus-líricos, expressa na heteronímia - resumida na noção de que "o poeta é um fingidor". A

7 "O meu estado de espírito obriga-me agora a trabalhar bastante, sem querer, no Livro do Desassossego. Mas tudo fragmentos, fragmentos, fragmentos". Carta de Pessoa a Armando Cortes-Rodrigues de 19 de novembro de 1914. Reproduzida em Pessoa (1944, p. 39). 
ideia de fragmentação talvez parecesse estranha para alguns personagens heteronímicos, em especial para o "mestre" Alberto Caeiro - cujos poemas de $O$ Guardador de Rebanhos teriam sido escritos todos de uma vez, num jato só, em pé, apoiado sobre uma cômoda, no "dia triunfal", segundo o conhecido relato de Pessoa - hoje amplamente questionado por estudiosos como Ivo Castro (2014) ou António Feijó (QUEIRÓS, 2014). Em todo caso, é interessante notar que a posição corporal rígida reforça a impressão de rigidez literária que produz uma obra igualmente rigorosa e totalizante. Muito diferente de seu mestre Caeiro, a fragmentação de Soares é assumida: o semi-heterônimo encarna em seu estilo literário fragmentário a problemática da fragmentação da própria personalidade. Em diversos trechos do Livro do Desassossego, é abordado o tema da diversidade versus unidade. Por isso é verdadeira (e não mera boutade) a afirmação feita por Zenith de que "Tivesse Pessoa preparado o Livro do Desassossego para publicação e este seria decerto um livro menor" (ZENITH, 1997, p. 31). Soares se enxerga tão múltiplo e disperso quanto seu livro. Afinal, o semi-heterônimo Bernardo Soares não é ele próprio considerado como um fragmento, uma "mutilação" da alma de Pessoa?

\section{Acaso}

É admirável observar que alguns importantes estudiosos pessoanos que se debruçaram sobre o Livro do Desassossego flertaram com a possibilidade de uma (des)organização aleatória dos trechos. O estudioso José Blanco (2008, p. 416) considera que o Livro do Desassossego pode ser organizado segundo os mais diferentes critérios, "inclusive a aleatoriedade": "é mesmo possível pensar-se numa edição em páginas soltas, como cartas de baralho, que possam ser lidas em infinitos arranjos". Ora, livros de páginas soltas são raros. Os Poemóbiles de Augusto de Campos, aos quais o artista Julio Plaza deu interessantes configurações espaciais, são um exemplo curioso: suas páginas têm um caráter único, bastante diferente dos livros "comuns", dado o seu aspecto escultórico. Não é difícil imaginar que um artista possa dar a páginas pessoanas um tratamento semelhante. Mas, em geral, os livros de páginas soltas, obviamente, constroem sentidos diferentes dependendo da ordem em que suas páginas são lidas. Paradoxalmente, livreiros e bibliotecários que se deparam com páginas soltas em livros comuns - páginas que se desgrudaram da cola das brochuras - sentem-se, 
naturalmente, compelidos a restituí-las a seu lugar de origem: geralmente são norteados pelo número indicado na paginação, mas há casos em que o número da página não é indicado (por exemplo, no início de um capítulo). Este caso, que levaria ao desespero os restauradores de livro, abre uma possibilidade para uma recriação involuntária. Certamente, dada sua própria natureza fragmentária, o Livro do Desassossego pode ser lido fora da ordem, não apenas pulando de um trecho para outro, mas também saltando de página em página, parágrafo em parágrafo, frase em frase, fragmento em fragmento, palavra em palavra - embaralhando e misturando os textos - de forma semelhante ao que sugere Tristan Tzara em sua receita de como fazer um poema dadaísta: recortar palavras, metêlas num saco e agitar suavemente. Este tipo de leitura caótica é proposto por um dos editores do Livro do Desassossego, embora não de forma tão radical: Richard Zenith (1997, p. 14), apesar de ter empreendido uma cuidadosa arrumação dos textos, aconselha na introdução à sua edição do Livro do Desassossego que este "seja lido sempre fora da ordem, que é a ordem correcta para ler esta coisa parecida com um livro". Talvez o mais intrigante seja o fato de Zenith ter partido de uma leitura caótica dos manuscritos, procurando "pescá-los" em meio à confusão dos números de tombo e da própria produção pessoana, ter levado em conta também a sua cronologia (mas sem se deixar nortear por ela)... e que depois de todo este percurso, partindo do caos e chegando à ordem (ou pelo menos a uma ordem), o próprio editor tenha desacreditado do seu poder de "domesticar" tais textos.

A noção de acaso é utilizada na ciência, nos jogos e na arte. Sabemos que criar o acaso é algo profundamente complexo, e que grande parte das decisões que supomos serem tomadas "ao acaso" obedecem às determinações mais diversas. Usar a inteligência artificial para gerar sequências aleatórias nem sempre constitui uma solução. A computação matemática distingue as sequências de números efetivamente aleatórias daquelas sequências chamadas de pseudoaleatórias, geradas por um algoritmo que procura imitar as propriedades das sequências de números aleatórios.

É possível que um livro impresso trabalhe com a noção de acaso? Ora, se pensássemos em obras em que as decisões do leitor definem a ordem - desde obras mais "sérias" como O jogo da amarelinha de Julio Cortázar até os livros-jogos de aventuras de tipo Role Playing Game (RPG) - seria possível imaginar uma ordenação do Livro do Desassossego 
que fosse sendo desenvolvida a partir das escolhas do leitor. Mas mesmo assim, não seria possível fugir à linearidade típica dos livros-jogos, nos quais, embora seja permitido fazer múltiplas escolhas, todas as opções já estão pré-definidas: os diversos caminhos que podem ser seguidos já estão pré-determinados pelo editor-autor.

\section{Virtualidade}

Em plena era cibernética, seria fácil imaginar uma transposição do Livro do Desassossego para uma plataforma virtual, semelhante a um hipertexto. É natural pensar o Livro do Desassossego dentro da ideia de virtualidade, já que ele é um mosaico que depende do trabalho do editor de "juntar os cacos". Como se, partindo das mesmas peças de um quebra-cabeça, fosse possível chegar, no final, a imagens diferentes; ou como se, colando os cacos de uma louça quebrada, fosse possível modelar diferentes peças.

A transposição do Livro do Desassossego para um formato digital permite manipulações que modificam o próprio estabelecimento do texto, segundo um determinado critério. Como se alteram as configurações de um programa de computador, ${ }^{8}$ o usuário-leitor-editor do texto virtual do Livro do Desassossego poderia então ir fazendo as suas escolhas para definir o texto que gostaria de ter diante dos olhos. Em plena era dos "algoritmos", poderíamos supor ainda que essas decisões (relativas à configuração de um possível livro-programa) poderiam ser tomadas automaticamente a partir de um algoritmo que resumisse a idiossincrasia daquele leitor - de forma semelhante à maneira como diferentes "conteúdos" são propostos em plataformas virtuais. Os usuários dos serviços Google têm a opção de "personalizar" as configurações das publicidades que vão receber. Ainda que o usuário opte por não fazer tais ajustes, a própria inteligência artificial reconhece e organiza traços de personalidade e gosto do usuário, a partir do tipo de "conteúdo" que ele acessa. Não é incomum que o usuário seja surpreendido por uma publicidade anunciando algo que pesquisou na busca do Google, ou algo de que tratou num e-mail privado. Da mesma forma, a inteligência artificial poderia se inspirar nestes traços de personalidade - desde a idade, o gênero, a profissão, o

\footnotetext{
${ }^{8}$ A comparação entre o livro e um programa de computador aparece em Melot (2012, p. 181).
} 
nível socioeconômico-cultural, até as marcas consumidas, os interesses pessoais, os gostos artísticos etc. - para gerar um Livro do Desassossego feito sob medida para cada usuário. Um ditado popular compara a vida a um livro aberto, traçando um paralelo entre a exibição da intimidade e a abertura de um livro. De forma semelhante, um eventual Livro do Desassossego, organizado a partir dos dados do algoritmo pessoal de alguém, deixaria supor traços de personalidade bastante íntimos - assim como, inevitavelmente, os diferentes editores do Livro do Desassossego deixaram impressas suas idiossincrasias nas diferentes edições, traduzidas na forma como interpretaram Pessoa.

Existem alguns interessantes projetos de "publicação" virtual da obra de Fernando Pessoa que ilustram as possibilidades abertas pela era cibernética. É o caso do Arquivo Pessoa (organizado pela Casa Fernando Pessoa), que reúne (em formatos HTML e PDF) boa parte da obra editada (em papel) de Pessoa. O website se absteve da tarefa de estabelecimento do texto, limitando-se a reproduzir as versões que foram adotadas em edições impressas as mais diversas.

Talvez procurando fugir a esta tarefa de estabelecimento do texto - e à obrigação de escolher entre as variantes postas no papel por Pessoa - surge outro curioso projeto: a Digital Edition of Fernando Pessoa organiza fac-símiles escaneados de manuscritos e datiloscritos de Pessoa: assim, o leitor pode ter diante de si o texto pessoano em sua versão mais crua. Enquanto edições críticas (como a organizada por Jerónimo Pizarro) e não críticas (como a princeps da Ática ou a organizada por Zenith) procuram criar simbologias para reproduzir as variações intratextuais, o projeto da Digital Edition of Fernando Pessoa simplesmente deixa ao leitor a tarefa de navegar o olhar pelo texto "original" em suas diversas ramificações - o que inclui, é claro, a tarefa ingrata, já mencionada, de decifrar os garranchos de Pessoa - tendo como apoio propostas de transliteração oferecidas pelo site.

Embora estes dois projetos digitais não se relacionem exclusivamente com o Livro do Desassossego, é claro que o antilivro fragmentário não deixaria de inspirar projetos de edições digitais e virtuais. Um interessantíssimo exemplo é o Arquivo LdoD, Arquivo Digital Colaborativo do Livro do Desassossego, criado pelo Centro de Literatura Portuguesa da Universidade de Coimbra. O projeto, que tem o interessante subtítulo Nenhum Problema Tem Solução: Um Arquivo 
Digital do Livro do Desassossego, é definido por seus criadores da seguinte forma:

O Arquivo LdoD é um arquivo digital colaborativo do Livro do Desassossego de Fernando Pessoa. Contém imagens dos documentos autógrafos, novas transcrições desses documentos e ainda transcrições de quatro edições da obra. Além da leitura e comparação das transcrições, o Arquivo $L d o D$ permite que os utilizadores colaborem na criação de edições virtuais do Livro do Desassossego. Inclui ainda um módulo de escrita que, futuramente, permitirá aos utilizadores escreverem variações a partir dos fragmentos do Livro. Deste modo, o Arquivo LdoD combina um princípio representacional com um princípio simulatório: o primeiro consiste na representação da história e dos processos de escrita e de edição do Livro; o segundo consiste na possibilidade de os utilizadores assumirem diferentes papéis no processo literário (ler, editar, escrever), usando a flexibilidade do meio digital para experimentarem o Livro do Desassossego como máquina literária.

As funcionalidades principais do Arquivo $L d o D$ têm expressão em seis menus diferenciados:

Leitura: leitura da obra de acordo com diferentes sequências;

Documentos: listagem de todos os fragmentos e informação acerca das fontes;

Edições: visualização dos originais e comparação das transcrições; Pesquisa: seleção de fragmentos de acordo com múltiplos critérios;

Virtual: criação de edições virtuais e suas taxonomias;

Escrita: escrita de variações a partir dos fragmentos [funcionalidade em desenvolvimento]. (PORTELA; SILVA, 2017)

Vemos portanto que o Arquivo $L d o D$ radicaliza propostas esboçadas por editores como Richard Zenith. Dá a cada leitor a possibilidade de resolver o problema da organização do Livro do Desassossego: qualquer usuário pode criar sua própria edição virtual da obra, deixando-a disponível para ser lida por outros usuários. Se, por um lado, a liberdade dada ao leitor-editor é imensa, ela não deixa de submeter-se a um número limitado de possibilidades combinatórias.

Diferentemente do livro de páginas soltas, nestes projetos digitaisvirtuais, a fronteira entre as páginas não é claramente definida. O livro em papel pressupõe a divisão estanque entre páginas (valendo-se do uso da 
dobra, no livro de tipo sanfonado): embora o livro seja entendido como um continuum, há uma descontinuidade entre cada unidade-página; ao mesmo tempo, as páginas contíguas estabelecem relações entre si, ainda que pertençam a partes diferentes do mesmo livro. Por outro lado, no caso do livro digital, a barra de rolagem relativiza as fronteiras da página impressa e torna mais fácil uma leitura contínua. Entretanto, tampouco na versão digital é possível ter uma visão da totalidade. O funcionamento da barra de rolagem do computador é comparável à pintura de rolo chinesa, que só pode mostrar um pedaço da imagem por vez. $\mathrm{O}$ cineasta e estudioso da montagem cinematográfica Serguei Eisenstein ${ }^{9}$ comparou a pintura de rolo chinesa à filmagem panorâmica. Em qualquer que seja a tela - do cinema, da televisão, do computador, do tablet, do celular, do leitor de livros digitais etc. - há sempre limites. Embora a paisagem ou o texto possam oscilar continuamente, existirão sempre fronteiras para emoldurá-los.

\section{1. À guisa de conclusão}

O Livro do Desassossego é um livro? Depende. Mas depende de quem? Basicamente de duas pessoas: do editor e do leitor. Em propostas mais radicais, como a do Arquivo LdoD, estas duas figuras podem estar fusionadas.

Geralmente, seja um editor-leitor, ou, separadamente, editor e leitor, entenderão um livro como um espaço normatizado, uma moldura que define os limites da obra artística. Mais radical ainda é essa noção para o Livro do Desassossego, cuja existência é meramente virtual, dependendo do trabalho do editor para "programar" a obra (guiando-se ou não pelas contraditórias "programações" deixadas por Pessoa). Depois de configurada, a obra deverá ser "executada" pelo leitor. Assim, por si só, o Livro do Desassossego não pode ser considerado um livro - pelo menos não dentro da concepção barthesiana do que "se segura na mão" (BARTHES, 2005). Ainda utilizando conceitos propostos por Roland Barthes, poderíamos pensar na oposição entre livro e álbum: fica evidente que o caráter fragmentário do Livro do Desassossego o aproximaria mais do álbum; porém, é igualmente evidente que o trabalho do editor, ao tratar de conferir àquela massa de fragmentos uma determinada coerência, o

${ }^{9}$ Um comentário sobre esta comparação de Eisenstein está em Deleuze (1985, p. 230). 
aproximaria imediatamente da noção barthesiana de livro - associada à ideia de perfeição e acabamento.

Num poema com o significativo título de Liberdade, Pessoa escreveu que "livros são papéis pintados com tinta", numa tentativa irônica de considerá-los como objetos de pouca importância. Mais irônico ainda é transpor esta noção para o Livro do Desassossego, uma obra que se dessacraliza ao ser organizada - e portanto transformada seja em "papel pintado com tinta", seja em "tela digital pintada com pixels" (se pensarmos em projetos digitais como o Arquivo LdoD). Ao se concretizar, o Livro do Desassossego perde seu caráter abstrato e inatingível. Hoje e sempre, organizar um Livro do Desassossego significará dialogar com todas as outras edições do Livro do Desassossego que já foram (e serão) organizadas.

\section{Referências}

BARTHES, Roland. A preparação do romance. Tradução de Leyla Perrone-Moisés. São Paulo: Martins Fontes, 2005.

BARTHES, Roland. Roland Barthes por Roland Barthes. Tradução de Leyla Perrone-Moisés. São Paulo: Cultrix, 1977. DOI: https://doi. org/10.1007/978-1-349-03518-2.

BLANCO, José. Livro do desassossego: História da Edição. In: MARTINS, Fernando Cabral. Dicionário de Fernando Pessoa e do Modernismo Português. Lisboa: Editoral Caminho, 2008. p. 416.

CASTRO, Ivo. Quantas horas tem um dia triunfal?. Revista Estranhar Pessoa, Lisboa, n. 1, p. 12-25, out. 2014.

COELHO, Jacinto Prado. Prefácio. In: PESSOA, Fernando. Livro do Desassossego por Bernardo Soares. Lisboa: Ática, 1982. p. 7.

DELEUZE, Gilles. Cinema I: a imagem-movimento. Tradução Stella Senra. São Paulo: Brasiliense, 1985.

ESTEVES, José Cerqueira; NEVES, João Miguel (ed.). Arquivo Pessoa. Lisboa: Obra Aberta CRL, 2008. Disponível em: http://arquivopessoa. net/. Acesso em: 31 ago. 2015.

FOUCAULT, Michel. O corpo utópico: as heterotopias. Tradução de Salma Tannus Muchail. São Paulo: N-1 Edições, 2013. 
GENETTE, Gérard. Paratextos Editoriais. Tradução de Álvaro Faleiros. São Paulo: Ateliê Editorial, 2009. (Artes do Livro, 7)

LIVRO do Desassossego. MARTINS, Fernando Cabral. Dicionário de Fernando Pessoa e do Modernismo Português. Lisboa: Editoral Caminho, 2008.

MARTINS, Fernando Cabral. Dicionário de Fernando Pessoa e do Modernismo Português. Lisboa: Editoral Caminho, 2008.

MELOT, Michel. Livro. Cotia: Ateliê Editorial, 2012.

OSAKABE, Haquira. O livro do mundo. In: NOVAES, Adauto. Poetas que pensaram o mundo. São Paulo: Companhia das Letras, 2005. p. 419-441.

PESSOA, Fernando. Cartas de Fernando Pessoa a Armando CôrtesRodrigues. Lisboa: Confluência, 1944.

PESSOA, Fernando. Da República (1910-1935). Lisboa: Ática, 1979.

PESSOA, Fernando. Livro do Desasocego. Editado por Jerónimo Pizarro. Lisboa: INCM, 2010. Tomos I e II.

PESSOA, Fernando. Livro do Desassossego por Bernardo Soares. Organizado por Maria Aliete Galhoz e Teresa Sobral Cunha. Lisboa: Ática, 1982.

PESSOA, Fernando. Livro do Desassossego. Composto por Bernardo Soares, ajudante de guarda-livros na cidade de Lisboa. Organizado por Richard Zenith. São Paulo: Companhia das Letras, 1997.

PESSOA, Fernando. Livro do Desassossego. Organizado por António Quadros. Sintra: Publicações Europa-América, 1986.

PESSOA, Fernando. Livro(s) do Desassossego. Edição de Teresa Rita Lopes. São Paulo: Global, 2015.

PESSOA, Fernando. Páginas íntimas e de auto-interpretação. Lisboa: Ática, 1966.

PORTELA, Manuel; SILVA, António Rito (org.). Arquivo LdoD: arquivo digital colaborativo do Livro do Desassossego. Coimbra: Centro de Literatura Portuguesa da Universidade de Coimbra, 2017. Disponível em: https://ldod.uc.pt. Acesso em: 31 ago. 2015. 
QUEIRÓS, Luís Miguel. O "dia triunfal” de Pessoa: uma ficção verdadeira. Público, Maia, mar. de 2014. Seção Ípsilon. Disponível em: https://www.publico.pt/2014/03/08/culturaipsilon/noticia/o-dia-triunfalde-pessoa-uma-ficcao-verdadeira-1627473. Acesso em: 31 ago. 2015.

RAMA, Ángel. A cidade letrada. Trad. Emir Sader. São Paulo: Editora Brasiliense, 1985.

SOARES, Bernardo. In: MARTINS, Fernando Cabral. Dicionário de Fernando Pessoa e do Modernismo Português. Lisboa: Editoral Caminho, 2008.

SEPÚLVEDA, Pedro; ULRIKE, Henny-Krahmer; URIBE, Jorge (ed.). Digital Edition of Fernando Pessoa: Projects and Publications. Lisbon and Cologne: IELT, New University of Lisbon and CCeH, University of Cologne, 2017. DOI: https://doi.org/10.18716/cceh/pessoa. Disponível em: http://www.pessoadigital.pt. Acesso em: 31 ago. 2015.

ZENITH, Richard. Introdução. In: PESSOA, Fernando. Livro do Desassossego. Composto por Bernardo Soares, ajudante de guardalivros na cidade de Lisboa. Organizado por Richard Zenith. São Paulo: Companhia das Letras, 1997. p. 13-36.

Recebido em: 30 de agosto de 2020. Aprovado em: 26 de janeiro de 2021. 